\title{
1. Introduction: civil wars and inclusivity
}

\section{INCREASING CIVIL WARS AND GLOBAL THREATS}

The 21 st century has been full of civil wars. According to Uppsala University Conflict Data Program (UCDP) data published in 2020, about 50 armed conflicts have been ongoing since the Arab Spring began in the Middle East in 2011. ${ }^{1}$ (Armed conflicts are defined as conflicts with more than 25 deaths in a year as a result of violent clashes, according to UCDP.)

Most armed conflicts in the 21 st century have been civil wars. In 2019, there were only two inter-state armed conflicts (conflicts between states); but 52 out of 54 armed conflicts were intra-state conflicts, which are virtually civil wars within a state. ${ }^{2}$

It is also critical that the number of intra-state conflicts in which troops from external states were involved - what we call "internationalized intra-state conflicts"-continued to rise. Within these 52 intra-state wars in 2019, 22 conflicts were internationalized, the highest number since $1946 .{ }^{3}$ The rise of internationalized civil wars, such as in Afghanistan, Iraq, Syria, Yemen, and Libya, has contributed to the highest number of armed conflicts since the end of World War II. Because of this high ratio of civil wars (intra-state conflicts) among the total number of armed conflicts in the current world, this book mainly focuses on how to address civil wars, including internationalized ones.

The high number of armed conflicts has caused approximately 100,000 deaths per year since 2011; armed conflicts also resulted in 80 million forcefully displaced people, including international refugees and internally displaced people (IDPs) all over the world in 2019. ${ }^{4}$ The United Nations (UN) High Commission for Refugees (UNHCR) declared that it "has not seen a higher total." ${ }^{\prime 5}$ This sharp increase in refugees has resulted in increasing populist movements against immigrants, shaking the international order.

Moreover, the high number of armed conflicts across the world makes it difficult for humans to tackle transnational, global, and nontraditional security challenges such as pandemics and global warming. When armed conflicts intensify, for instance, it becomes extremely difficult to address the global pandemics caused by COVID-19, simply because medical staff cannot enter the affected areas for security reasons. ${ }^{6}$ That is why UN Secretary-General 
António Guterres appealed for a "global ceasefire" in March 2020, responding to the worldwide expansion of COVID-19.7 The question is "how?"

\section{THE IMPORTANCE AND DIFFICULTY OF INCLUSIVITY IN PEACEBUILDING}

The aim of this book is to illuminate how we can solve civil wars by focusing on the question of inclusivity in both mediation during armed conflicts and post-conflict peacebuilding. With regard to post-conflict peacebuildingdomestic and international efforts to create sustainable peace in the aftermath of armed conflicts - there is a growing consensus that inclusivity is one of the most important factors in overcoming intra-state conflicts (civil wars) and establishing sustainable peace. In April 2016, both the UN Security Council and the UN General Assembly unanimously adopted the same resolution, "Review of the United Nations Peacebuilding Architecture." This landmark resolution on peacebuilding emphasizes that "inclusivity is key to advancing national peacebuilding processes and objectives in order to ensure that the needs of all segments of society are taken into account." "This was the first time the UN member states adopted a resolution to express the importance of inclusivity in post-conflict peacebuilding unanimously and so clearly. The resolution was reflected in the accumulated claims by both practitioners and scholars that inclusivity is critical in establishing sustainable peace. ${ }^{10}$

I have also been emphasizing the importance of inclusivity (or inclusiveness) in post-conflict peacebuilding since 2008 when I published my report to the UN Department of Peace Keeping Operations (DPKO) based on my field research in Afghanistan. ${ }^{11}$ In 2015, I published the book Challenges of Constructing Legitimacy in Peacebuilding: Afghanistan, Iraq, Sierra Leone, and East Timor, focusing on the importance of inclusivity in post-conflict peacebuilding. ${ }^{12}$ In terms of legitimacy, Ian Hurd defines legitimacy as "a normative belief by actors that a rule or institution is to be obeyed." 13 In other words, legitimacy is a normative concept that drives compliance not by coercion but "in a voluntarist mode." ${ }^{14}$ Thus, once the governments in post-conflict settings become legitimate in the eyes of local people, it is very likely that these states will establish peace and stability, at least within the state, as the majority of people comply with the rules and institutions of their governments in a voluntarist mode.

In my book Challenges of Constructing Legitimacy in Peacebuilding, I argue that there are four key factors in creating repeated compliance and establishing legitimate governments in the long run in conflicted states: (1) credible third parties (and the UN has some comparative advantage in its impartiality and credibility), (2) inclusive political processes (not excluding particular ethnic, or religious, or political groups in the nation-building pro- 
cesses), (3) resource distribution (improving the living conditions of people), and (4) level of force (raising the capacity of security sectors). My argument is illustrated in Figure 1.1..$^{15}$

\section{Critical Factors that might have impacts on creating a new legitimate government in post-conflict states}

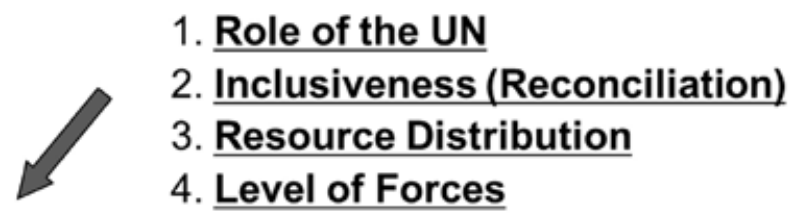

Credibility as Impartial
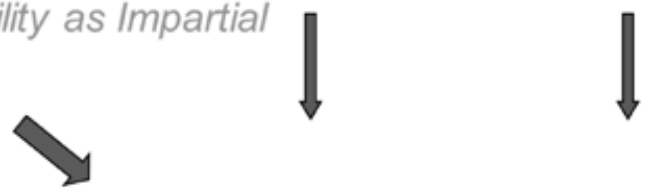

Compliance Non-Compliance (to Election, Constitution, Demobilization)

Repeated Compliance

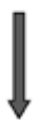

Legitimate Government
Repeated Non-Compliance

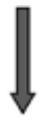

\section{Erosion of Government}

Figure 1.1 My argument on constructing domestic legitimacy in peacebuilding

I emphasized that in addition to resource distribution and level of force, the existence of credible third parties and inclusive political processes are crucial in creating repeated compliance, and legitimate governments in the long run, in war-torn states.

While attention to the importance of inclusivity has been growing in both UN documents and scholarly studies, the implementation of inclusive national processes has been extremely challenging and difficult in many conflicted 
states. Utilizing my theoretical framework, I have been doing field research to examine the challenges of creating inclusive political processes in different conflicted zones, such as Afghanistan, South Sudan, Syria, Iraq, Yemen, and East Timor, since 2016. ${ }^{16}$

\section{MY ARGUMENT ON INCLUSIVITY IN MEDIATION DURING ARMED CONFLICTS}

My field research on these critical civil wars gave me a perspective that there must be different natures of inclusivity in mediation during armed conflicts and post-conflict peacebuilding. While it is becoming a consensus that inclusivity is key to successful post-conflict peacebuilding - as shown in the previous section - there is little understanding and even confusion about inclusivity in the "mediation during armed conflicts" phase. Based on field research I conducted in the last several years and scholarly investigations, I argue in this book that a more flexible approach is necessary with regard to inclusivity in the "mediation during armed conflicts" phase.

This book aims to clarify these different natures of inclusivity during different phases, as well as to illuminate the challenges of the UN, neighboring states, and global powers in the phases of "mediation during armed conflicts." I argue that in mediation during armed conflicts, it is necessary to accept more flexible approaches to inclusivity. There are certain cases in which the most influential groups need to be selected for peace negotiations to achieve peace agreements and ceasefires; mediators will then outreach to and create comprehensive agreements with the participation of the members of the larger groups. It is necessary to recognize that there is the risk of failing to establish a peace agreement if you only pursue inclusion of broader military and political parties in the phase of mediation during armed conflicts. ${ }^{17}$ On the other hand, it is crucial for peace processes to include all factions in society as broadly as possible in the phase of post-conflict peacebuilding.

\section{ROLES OF THE UN, NEIGHBORING STATES, AND GLOBAL POWERS}

In this book, I also argue that key mediators would be different during the different phases of armed conflicts. In post-conflict peacebuilding, the UN should play a central role as an international actor supporting domestic stakeholders to consolidate peace. As Minxin Pei and Sara Kasper assert, leading roles by powerful states in nation-building could be seen as quasi-colonialism in the eyes of local people in these host states. ${ }^{18}$ There is much evidence that the UN at least has a comparative advantage in obtaining trust as fair and impartial in the eyes of local people, compared with powerful states, in the post-conflict 
Table 1.1 Inclusivity and the roles of international actors

\begin{tabular}{lll}
\hline & $\begin{array}{l}\text { Mediation during armed conflicts } \\
\text { (Peace negotiation phase) }\end{array}$ & Post-conflict peacebuilding \\
\hline Inclusivity & $\begin{array}{l}\text { Inclusivity needs to be flexible in order } \\
\text { to reach a peace agreement. }\end{array}$ & $\begin{array}{l}\text { Inclusivity (avoiding political } \\
\text { exclusion) is key to success. }\end{array}$ \\
International actors & $\begin{array}{l}\text { Global powers and neighboring states } \\
\text { have primary responsibilities. }\end{array}$ & $\begin{array}{l}\text { United Nations should play } \\
\text { a central role. }\end{array}$ \\
\hline
\end{tabular}

peacebuilding phase; I demonstrated this comparative advantage with many opinion surveys and analyses on the motives of stakeholders in conflicted states in my previous book. ${ }^{19} \mathrm{I}$ will also present the recent scholarly findings in this regard in Chapter 2.

On the other hand, the role of the UN can be very limited in mediation during armed conflict, especially when the global powers and neighboring states are divided on the strategy to end wars. In other words, it is global powers and neighboring states that have primary responsibilities and leverage in persuading conflicting parties to stop armed conflicts and create peace accords, which might result in lasting peace. Table 1.1 summarizes my arguments.

I have no intention to downgrade the efforts by the UN to mediate armed conflicts: Many UN special envoys are working hard to convince conflicting parties to agree on ceasefires and to sign peace accords for lasting peace, including in Syria and Yemen. But these UN efforts have not been so successful, especially in the 21 st century. ${ }^{20}$ I would like to articulate that there are structural factors affecting the performance of UN mediators. In many cases, it is not because of a lack of capability of the UN mediation teams. When neighboring states and global powers continue to support conflicting parties with military and financial aid, seeking the military victory of the parties that they are supporting, it is simply difficult - maybe impossible - for UN mediators to stop wars. The global and regional powers might appeal or make a gesture that they are supporting efforts by UN mediators while they keep supporting their protégés financially and militarily. In these circumstances, some might argue that the UN is literally "abused" by global powers and neighboring states who have no serious intention to achieve a peaceful settlement, but seek one-sided military victory by supporting the parties that they favor. It is critical that global powers and neighboring states should share the same strategy on how to end civil wars with peaceful settlement and collaborate to push the conflicting parties to stop military operations and sign agreements. ${ }^{21}$

Only once the global powers and neighboring states jointly attempt to convince conflicting parties to stop fighting and to sign peace accords can the UN play a critical role in facilitating discussion between conflicting parties. Stephen John Stedman argued in his milestone article on mediation in internal 
conflict that "when concerned member states reach a consensus on how to terminate war, the United Nations can be an effective agent for bringing this about." ${ }^{22}$ After the peace agreement is signed and efforts for peacebuilding begin, the UN may play a critical and central role in dispatching UN peacekeepers and UN field missions; UN missions could support local stakeholders in the implementation of peace accords, which would include the adoption of a new constitution, the creation of government institutions, and the conduct of new elections. The roles of the UN, neighboring states, and global powers will be discussed in detail in Chapter 2.

\section{STRUCTURE OF THE BOOK}

This book consists of eight chapters. Chapter 2 examines scholarly arguments and debates on inclusivity in mediation during armed conflicts and post-conflict peacebuilding. I will also examine several key UN documents, including the resolutions of the UN General Assembly on mediation in 2014, for which I was involved in the negotiation process and directly witnessed the different perspectives on the question of inclusivity in mediation during armed conflicts. Chapter 2 also introduces key debates on international actors on both mediation during armed conflicts and post-conflict peacebuilding.

Chapter 3 examines the peace processes of South Sudan to illustrate how the question of inclusivity needs to be flexible in some mediations during armed conflicts. After South Sudan had a second relapse of civil war in July of 2016, the Intergovernmental Authority on Development (IGAD, the East Africa regional organization) played a central role in revitalizing the peace process. ${ }^{23}$ Reflecting on previous failures to implement peace agreements between the factions of President Salva Kiir and Vice President Riek Machar, IGAD decided to invite almost all political groups from South Sudan, and more than 20 groups participated in the peace negotiation in Addis Ababa at the end of 2017. However, after several rounds of negotiations, the leadership of IGAD, such as the heads of Ethiopia, Kenya, Uganda, and Sudan, found that it was just impossible for these large groups to reach any peace agreement. Thus, Sudan, which had been supporting Vice President Machar, and Uganda, which had been supporting President Kiir, decided to take both Machar and Kiir to Khartoum, the capital of Sudan, in June 2018, and the presidents of Sudan and Uganda worked together to convince President Kiir and Vice President Machar to reach a basic agreement. ${ }^{24}$ Due to this unprecedented joint effort by Sudan and Uganda, President Kiir and Vice President Machar agreed on the basic framework of the peace agreement, and IGAD outreached to other political groups, and succeeding in signing a comprehensive peace agreement in September 2018. ${ }^{25}$ After this agreement in 2018, although there have been many delays and challenges in the implementation, the basic components of 
the peace accords, including a ceasefire, have been maintained in South Sudan until now (as of writing in October 2021).

Chapter 4 examines the peace processes of Afghanistan. The development of Afghan peace negotiations demonstrates a similar trend with regard to the need for a flexible approach in mediation during armed conflicts. Since 2010, there have been repeated suspensions of the peace negotiations by the Afghan government, the Taliban, United States (US), and Pakistan, mediated by Qatar. ${ }^{26}$ It was only after the US decided to have a bilateral negotiation with the Taliban in 2018 that they became able to maintain sustainable talks. After more than ten rounds of negotiations, the US and the Taliban finally signed an agreement in February 2020. The US would withdraw its forces from Afghanistan in 14 months; in exchange, the Taliban would make its best efforts to prevent Al-Qaida or ISIS from being deployed and active in Afghanistan. ${ }^{27}$ Based on this bilateral agreement, the Afghan government and the Taliban launched their first official peace negotiations in Doha, the capital of Qatar, in September 2020. ${ }^{28}$ In April 2021, US President Biden announced that he would withdraw all American forces from Afghanistan by the end of August 2021. With the peace negotiations between the Afghan government and the Taliban at a stalemate, at the beginning of August 2021 as the US forces began withdrawing, the Taliban started comprehensive military campaigns to capture the provincial capitals of 34 provinces across the country. After a few days' fighting in early August, the Afghan government forces decided to surrender to the Taliban across the country; as a result, the Taliban controlled the entire country, including Kabul, by the middle of August. This military surrender was coordinated by the Afghan government officials who had regular contact with the Taliban delegates in Doha and decided to avoid an all-out war among the Afghan people after the withdrawal of US forces. This astonishing development demonstrates how peace negotiations can result in unintended consequences - in this particular case, the democratic state collapsed, but all-out and long-lasting civil war after the withdrawal of US forces was avoided by the coordination between the Afghan government and the Taliban in Doha (thus, it is difficult to deny the significance of the peace talk totally).

Chapter 5 will present case studies of Syria to examine the roles of the UN, neighboring states, and global powers in mediation during armed conflicts. The case of Syria clearly demonstrates the phenomenon of the "abuse" of the UN. ${ }^{29}$ UN special envoys (four envoys from 2012 to 2020) continue shuttle diplomacy to make peace agreements between the Assad regime and opposition groups in Syria. The global powers, such as the US and Russia, and regional powers, such as Iran, Saudi Arabia, Turkey, Qatar, and United Arab Emirates (UAE), keep announcing their support for UN mediation efforts in Syria. However, on the ground, Russia and Iran have been supporting the Assad regime, including massive and determined military interventions. On 
the other hand, the US, Saudi Arabia, Qatar, and Turkey have been supporting the opposition with massive military and financial assistance. As a result, the UN mediation efforts have failed to arrive at any peace agreement for a decade. ${ }^{30}$ The development of Syrian internationalized civil war clearly shows how global powers and neighboring states could abuse the UN and derail peace processes.

Chapter 6 examines the peace process of Yemen, which is also a typical case of the failure of the mediation, due to the lack of a cohesive approach by neighboring states and global powers. Saudi Arabia and UAE began massive military interventions into Yemen in 2015 after the Houthis, an Iran-backed faction, gained control of Sana'a, the capital of Yemen. ${ }^{31}$ Due to the harsh fighting, Yemen became one of the worst humanitarian catastrophes in the world. In spite of continuous effort by UN special envoys for Yemen, the fighting continues because Saudi Arabia and UAE have continued supporting the Yemen government while Iran keeps providing the Houthis with military and financial aid. The several years' experience of Yemen's internationalized civil war demonstrates how regional and global powers have critical roles in continuing or ending war, and mediation by the UN cannot be effective when regional and global powers are divided.

Chapter 7 will examine the peacebuilding efforts of Iraq and East Timor to confirm how inclusive political processes have been crucial in the phase of post-conflict peacebuilding. In Iraq, US forces toppled the regime of Saddam Hussain and began nation-building in 2003. However, the disbandment of the Iraq National Army and Ba'ath Party by the US occupational authority was a typical exercise in political exclusion, in this case against Saddam Hussain's Sunni political factions. ${ }^{32}$ This political exclusion resulted in all-out civil war in Iraq in 2006. After US forces decided to include most of the Sunni insurgent groups in Iraqi government institutions (Iraqi Awakening Councils) with some payrolls across the country in 2007 , the security situation was drastically improved. ${ }^{33}$ Just after US forces withdrew from Iraq in 2012, however, the political exclusion of Sunni political leaders and populace started again, and ISIS took over one-third of the country in 2014 by utilizing the grievances of Sunni people in Iraq. It took three years for the Iraqi government and international forces, including the US and Iran, to regain most of the territory from ISIS at the end of $2017 .{ }^{34}$ As it continues to suffer from political instability and fragility, Iraq keeps struggling to find real national reconciliation across different religious sects and political groups.

On the other hand, the case of East Timor gives us key indications about how UN-led peacebuilding can successfully achieve inclusive nation-building after civil war. After a national referendum in 1999, UN peacekeeping missions played a vital role in creating a new state in East Timor. ${ }^{35}$ One year after the UN peacekeeping mission withdrew from East Timor in 2005, there was 
a political crisis in 2006 when the rival factions of Xanana Gusmão (president at that time) and Mari Alkatiri (prime minister at that time) clashed, resulting in 100,000 internal refugees. But the international community, led by Australia, quickly intervened in the crisis by dispatching multinational forces. The UN integrated mission in East Timor resumed the stabilization and nation-building and conducted a national election in $2007 .{ }^{36}$ The critical development was that after Gusmão became the new prime minister, he approached Alkatiri and his party (FRETILIN) - the largest opposition party - to advance national reconciliation and respect the participation of FRETILIN in the decision-making process. In 2015, when Gusmão stepped down, he even appointed Rui Araujo, who was a member of FRETILIN and the subordinate of Alkatiri, as his successor. ${ }^{37}$ This appointment drastically improved trust between Gusmão and Alkatiri, and they began working together on the final stages of nation-building in East Timor. The case of East Timor clearly demonstrated how inclusivity is key in sustaining peace in post-conflict peacebuilding and how UN field missions can play a central role in supporting it. In Chapter 8 (the conclusion chapter), I will conclude my argument, with some theoretical and policy implications, and pose key remaining questions for future research agendas.

\section{METHODOLOGY}

I examine my arguments with detailed analysis of peace processes in each conflict. On South Sudan, I have been conducting the field research in neighboring states since 2016 and accumulated interviews with political leaders of the factions of both President Kiir and Vice President Machar and numerous mediators from the UN, African Union, and IGAD. I was also assigned by the Japanese Foreign Minister to visit South Sudan in 2019 to make intellectual contributions to peacebuilding and to interview prominent figures, including the first vice president, other cabinet members, and opposition leaders in South Sudan. In 2018 and 2019, I was also assigned by the foreign minister to visit Iraq to interview top leadership, including three vice presidents of Iraq who represent Shia, Sunni, and Kurd political factions.

In terms of Syria and Yemen, the field research was conducted in 2017, 2018, and 2020 in Lebanon, Amman, and Geneva with interviews with key actors, including the UN special envoy for Syria; the representatives of Syria (Syrian ambassador in Geneva), Russia, Iran, and the representatives of Saudi Arabia, Qatar, Turkey, European Union (EU), and US. The field research was also conducted in East Timor in 2017 with hour-long interviews with both Xanana Gusmão and Mari Alkatiri, who have been key players in nation-building in East Timor. With regard to Afghanistan, I conducted academic research on challenges of Afghan reconciliation in 2008 and worked for the UN Assistance Mission in Afghanistan (UNAMA) in 2009 and 2010 
as a team leader for reconciliation and reintegration and supported the Afghan government to establish key mechanisms for starting political negotiations with the Taliban. Since then, I have been following the development of Afghanistan with academic exercises, including hosting numerous conferences and seminars on this agenda.

The initial findings of these field researches on South Sudan, Afghanistan, Syria, and Yemen were shared in a seminar hosted by the International Peace Institute (IPI) in New York on "The Importance of Inclusivity in Peacebuilding and Sustaining Peace" in June 2018, as well as through lectures at UN Headquarters, hosted by UN Peace Building Support Office (PBSO) in 2016, 2017, and 2019, with the feedback and insights from UN practitioners, diplomats, think tank analysts, and scholars for constructing this book. ${ }^{38}$

\section{NOTES}

1. Therese Pettersson and Magnus Oberg, "Organized Violence, 1989-2019," Journal of Peace Research 57, no. 4 (2020).

2. Ibid., 599.

3. Ibid., 599.

4. UNHCR, “Global Trends Forced Displacement in 2019," June 2020. Available at: https://www.unhcr.org/globaltrends2019/, accessed October 2021.

5. UNHCR Press Release, "1 per cent of humanity displaced: UNHCR Global Trends report," June 18, 2020.

6. For instance, the international response to the Ebola outbreak in the Democratic Republic of the Congo (DRC) in 2018 was hampered by the military fighting as medical staff were frequently attacked; as a result, the outbreak lasted much longer and resulted in more deaths (with a confirmed 2,264 fatalities) than would have been the case without the armed conflict. (International Crisis Group, "COVID-19 and Conflict: Seven Trends to Watch," Special Briefing 4, March 24, 2020.)

7. António Guterres, "Secretary-General's Appeal for Global Ceasefire," March 23, 2020.

8. Twin resolution adopted by UN Security Council and UN General Assembly on April 27, 2016, "Review of the United Nations Peacebuilding Architecture," A/ $\mathrm{RES} / 70 / 262$ and $\mathrm{S} / \mathrm{RES} / 2282$.

9. Ibid., 1.

10. One of the prominent works for this matter is Charles T. Call, Why Peace Fails: The Causes and Prevention of Civil War Recurrence (Washington, DC: Georgetown University Press, 2012). You may see key literatures and debates on inclusivity in peacebuilding in Chapter 2.

11. Daisaku Higashi, "Challenges of Constructing Legitimacy in Peacebuilding: Case of Afghanistan," The Best Practices Section of UN Department of Peacekeeping Operations, 2008. Available at: https://www.jica.go.jp/story/interview/pdf/afghan .pdf, accessed October 2021.

12. Daisaku Higashi, Challenges of Constructing Legitimacy in Peacebuilding: Afghanistan, Iraq, Sierra Leone, and East Timor (London and New York: Routledge, 2015). 
13. Ian Hurd, "Legitimacy and Authority in International Politics", International Organizations 53, no. 2 (1999): 381.

14. Thomas Franck, The Power of Legitimacy Among Nations (New York: Oxford University Press, 1990): 26.

15. Figure 1.1 from Higashi, Challenges of Constructing Legitimacy in Peacebuilding.

16. I utilized public research funds (KAKENHI, grant for scientific research from the Ministry of Japanese Education) titled, "Peacebuilding and Political Exclusion" (from 2016 to 2018) and "Peacebuilding and Political Parties: How Can Insurgency Be Transformed into Political Parties?" (from 2019 to the present).

17. The scholarly debate on this issue will be discussed in detail in Chapter 2 .

18. Minxin Pei and Sara Kasper, "Lessons from the Past: The American Record on Nation Building," Policy Brief, Carnegie Endowment for International Peace (2003): 5. Available at: http://www.carnegieendowment.org/files/Policybrief24 .pdf, accessed October 2021.

19. The book, Challenges of Constructing Legitimacy in Peacebuilding (2015) illuminates how the UN has a comparative advantage to be seen as fair and impartial actors, compared with powerful states, such as the US in the context of Iraq and Afghanistan, Australia in East Timor, and Nigeria in Sierra Leone. There are scholarly reviews on this question in Chapter 2.

20. Tetsuro Iji claims that there were not so many successful UN mediations in the 20th century and argues that only when P5 members of the UN Security Council are united can the UN play an effective role as a mediator. See Tetsuro Iji, "The UN as an International Mediator: From the Post-Cold War Era to the Twenty-First Century," Global Governance 23, no. 1 (2017). These discussions will be reviewed in detail in Chapter 2. With regard to the case studies of Syria and Yemen, see Chapter 4. With regard to Libya, see International Crisis Group, "Of Tanks and Banks: Stopping a Dangerous Escalation in Libya," May 20, 2019. Available at: https://www.crisisgroup.org/middle-east-north-africa/north-africa/libya/201 -tanks-and-banks-stopping-dangerous-escalation-libya, accessed October 2021, and International Crisis Group, "Interpreting Haftar's Gambit in Libya," May 4, 2020. Available at: https://www.crisisgroup.org/middle-east-north-africa/north -africa/libya/interpreting-haftars-gambit-libya, accessed October 2021.

21. The 2018 peace agreement of South Sudan, which will be examined in Chapter 3, clearly illuminates the criticality of the joint efforts by neighboring states.

22. Stephen John Stedman, "Negotiation and Mediation in Internal Conflict," in The International Dimensions of Internal Conflict, ed. Michael Brown (Cambridge, MA: The MIT Press, 1996): 362. The scholarly debates on this regard will be discussed in Chapter 2.

23. Redie Bereketeab, "The Collapse of IGAD Peace Mediation in the Current South Sudan Civil War," Journal of African Foreign Affairs 4 (2017).

24. See the details of the revitalized peace process of South Sudan in Chapter 3.

25. Signed Revitalized Agreement on the Resolution of the Conflict in South Sudan, 2018. Available at: https://igad.int/programs/115-south-sudan-office/1950-signed -revitalized-agreement-on-the-resolution-of-the-conflict-in-south-sudan, accessed October 2021.

26. See the details of the Afghan peace process in Chapter 3. The peace process of Afghanistan until 2014 was also described in detail by Higashi, Challenges of Constructing Legitimacy in Peacebuilding, Chapter 3.

27. Agreement for "Bringing Peace to Afghanistan between the Islamic Emirate of Afghanistan which is not recognized by the United States as a state and is known 
as the Taliban and the United States of America," February 29, 2020. Available at: https://www.state.gov/wp-content/uploads/2020/02/Agreement-For-Bringing -Peace-to-Afghanistan-02.29.20.pdf, accessed October 2021.

28. BBC News, "Afghan-Taliban peace talks an 'opportunity for peace'," September $12,2020$.

29. The details of analysis on the Syrian peace process is given in Chapter 4 .

30. See for instance, Ingrid Habets, "Obstacles to a Syrian Peace: The Interference of Interests," European View 15, no. 1 (2016) and Robert Ford, "Keeping Out of Syria," Foreign Affairs 96, no. 6 (2017).

31. The details of analysis on the Yemen peace process is described in Chapter 4.

32. The details of analysis on the Iraq peacebuilding process is given in Chapter 5 .

33. Steven Simon, "The Price of Surge: How U.S. Strategy is Hastening Iraq's Demise," Foreign Affairs 87, no. 3 (2008).

34. Linda Robinson, "Winning the Peace in Iraq," Foreign Affairs 98, no. 5 (2019).

35. The details of analysis on the East Timor peace-building is described in Chapter 5.

36. Pauline Tweedie, "Twenty Years of Elections and Democracy in Timor-Leste," The Asian Foundation, 2019. Available at: https://asiafoundation.org/2019/08/28/ twenty-years-of-elections-and-democracy-in-timor-leste/, accessed October 2021.

37. David Webster, "15 Years after Independence, Whatever Happened to East Timor?" Asia Pacific Foundation of Canada, 2017. Available at: https://www .asiapacific.ca/canada-asia-agenda/15-years-after-independence-whatever -happened-east-timor, accessed October 2021.

38. The article about the seminar on "Importance of Inclusivity in Peacebuilding and Sustaining Peace" hosted by International Peace Institute (IPI) on June 12, 2018 can be seen in the link: https://www.ipinst.org/2018/06/inclusivity-and-sustaining -peace\#13, accessed October 2021. 